\title{
The efficacy of clinical pathway in gastric cancer surgery
}

\author{
Ali Güner ${ }^{1,2}($ ID) \\ ${ }^{1}$ Department of General Surgery, Karadeniz Technical University School of Medicine, Trabzon, Turkey \\ ${ }^{2}$ Department of Biostatistics and Medical Informatics, Karadeniz Technical University Institute of Medical Science, Trabzon, Turkey
}

ABSTRACT

Objective: Clinical pathways are useful tools for surgical quality improvement and better peri-operative clinical outcomes for patients undergoing major surgery. This study aimed to evaluate the influence of clinical pathway on early postoperative outcomes for gastric cancer patients.

Material and Methods: The study was designed as a retrospective cohort observational study. Patients who had undergone curative gastrectomy for gastric cancer were evaluated by using the gastric cancer database, which was prospectively maintained. The patients were divided into two groups based on the date when the clinical pathway was first used: The control group (May 2015-May 2016) and the clinical pathway group (June 2016-December 2017). Early postoperative outcomes including the length of hospital stay, start of the day of diet, and 30-day complications including reoperation, and operative mortality were compared after propensity score matching.

Results: A total of 101 patients were analyzed, and the data of 70 patients (35 patients in each group) were compared after matching. Clinical pathway group demonstrated shorter hospital stay, earlier nasogastric tube removal, and start of earlier liquid/soft diet. Overall complication rate was lower in the clinical pathway group, while there was no statistically significant difference in major complication rates. No statistically significant difference was observed between the groups in terms of reoperation and operative mortality.

Conclusion: Clinical pathway may shorten the postoperative length of hospital stay and reduce the overall complication rate without increasing major morbidity in patients undergoing elective gastric cancer surgery.

Keywords: Gastrectomy, gastric cancer, clinical pathway, perioperative care, recovery of function, quality improvement

Cite this article as: Güner A. The efficacy of clinical pathway in gastric cancer surgery. Turk J Surg 2020; 36 (1): 39-47.

\section{Corresponding Author}

Ali Güner

E-mail: draliguner@yahoo.com

Received: 15.10.2019

Accepted: 04.11.2019

Available Online Date: 18.03.2020

O Copyright 2020 by Turkish Surgical Society Available online at www.turkjsurg.com

DOI: $10.5578 /$ turkjsurg.4547

\section{INTRODUCTION}

Hospitals, which are complex organizations consisting of many interconnected actions, are designed for patient-centered and effective healthcare $(1,2)$. Having been managed with traditional concepts for many years, total quality management is now a new paradigm in healthcare organizations $(3,4)$. Various strategies, such as enhanced recovery, outcome management, and integrated care pathways can be used as part of total quality management (5). Clinical pathways (CP), which are standardized comprehensive management systems, are useful tools for surgical quality improvement, designed to improve peri-operative outcomes such as hospital stay, morbidity, and cost $(6,7)$. Effectiveness of CP for cardiothoracic, liver, and bariatric surgery has been shown in recent studies (7-10).

One of the major causes of cancer-related deaths, the only treatment option of gastric cancer in a majority of patients is surgical resection $(11,12)$. However, gastrectomy for gastric cancer remains a high-risk procedure with significant morbidity and mortality $(13,14)$. Clinical pathway has also been used for gastric cancer surgery, and studies have demonstrated improvement in peri-operative outcomes (15-18). Enhanced Recovery After Surgery (ERAS) protocol is an evidence-based model of standardized clinical pathway system, which has been considered safe and effective in a recent meta-analysis in gastrectomy for gastric cancer patients (19). Besides, consensus guidelines for enhanced recovery after gastrectomy has been published by the ERAS ${ }^{\circledR}$ society (20). However, majority of the evidence regarding enhanced recovery pathways has originated from studies conducted in far eastern countries. Convincing evidence from western patient population is limited, and thus, the feasibility of clinical pathways in all gastric cancer patients, particularly in developing countries, remains controversial. 
Clinical pathway system, as part of a quality improvement program for gastric cancer patients, was implemented in June 2016 in a tertiary center from Turkey. In the present study, the influence of clinical pathway on early postoperative outcomes for gastric cancer patients was evaluated.

\section{MATERIAL and METHODS}

\section{Patients and Data Collection}

The study was designed as a retrospective cohort observational study. The database prospectively maintained for patients who had undergone surgical treatment for gastric cancer was reviewed. CP for gastric cancer surgery was implemented in June 2016 and modified in December 2017 with the use of a checklist system. Therefore, patients operated on in this period were selected as test group (CP group). Before the implementation of $\mathrm{CP}$, patients were managed without any specific protocol, and these patients were selected as the historic control group (control group). Patients operated on before May 2015 were excluded to decrease the risk of experience bias. Signed informed consent was obtained from all patients prior to surgery. Ethics permission for the study was obtained from the ethics committee (2019/177).

All consecutive patients who had undergone gastrectomy for gastric malignancy between May 2015 and December 2017 were evaluated. Exclusion criteria were: (1) patients who did not have gastric resection, (2) patients who only had palliative procedure including bypass or palliative resection (3) patients having distant metastasis, (4) patients requiring thoracotomy, (5) emergency surgery, and (6) patients who had malignancy other than adenocarcinoma.

All data were retrieved from the electronic database developed in 2013 for patients who underwent upper gastrointestinal cancer surgery. The following data regarding patient demographics and clinical characteristics were extracted: age, sex, body mass index (BMI), American Society of Anesthesiologists (ASA) score, history of previous abdominal surgery, smoking habits, hemoglobin level, albumin level, tumor size, histologic differentiation, type of gastrectomy, type of lymphadenectomy, source of tumor, presence of neoadjuvant treatment, pathological stage, total number of removed lymph nodes. Surgical principles were in accordance with the Korean and Japanese gastric cancer treatment guidelines $(21,22)$. D2 lymphadenectomy for advanced gastric cancer and D1+ lymphadenectomy for early gastric cancer were standard approaches, while D1 gastrectomy was used seldom in high-risk patients (23). Tumors were staged according to the 8th edition of the American Joint Committee on Cancer Staging System $(24,25)$.

Outcome measures were the length of hospital stay, the day of nasogastric tube removal, the day of starting sips of water (SOW), the day of starting soft diet, the day of drain removal, 30-day complication rate, 30-day reoperation rate, and operative mortality. Adverse events occurring within 30 days after surgery or within the hospitalization period were considered postoperative complications. Complications were classified according to the Clavien-Dindo classification system (26). Complications classified as grade 3 or higher were defined as major complications. Mortality that occurred within 30 days after surgery or during initial hospitalization was defined as operative mortality.

\section{Clinical Pathway for Gastric Cancer Surgery}

$\mathrm{CP}$ for gastric cancer surgery has initially been developed according to the current evidence on CP and published ERAS protocol for gastric cancer surgery and modified based on the institutional facilities and personal experiences (20). CP is summarized in Table 1. In brief, we divided peri-operative process into three main periods. The first period (preoperative preparation period) starts at the time when the patient's initial diagnosis of gastric cancer is established and is is primarily focused on the conformity of indication of surgical treatment, optimizing chronic diseases, nutritional counseling, and patient/family member's education.

The second period (operative period) starts with the patient's admission for surgery, typically one day before the scheduled operation date, and ends when the patient comes back to the wardroom after surgery. Confirming the completeness of the preparation and the surgical procedure are the main elements of the second period. During operation, intra-abdominal drain and nasogastric tube are routinely used regardless of the gastrectomy type. Because the majority of the patients had advanced gastric cancer or tumors requiring total gastrectomy, laparoscopic approach was seldom used in the study period only for early gastric cancers requiring distal gastrectomy (23).

The third period (postoperative care) primarily focused on postoperative care and ended when the patient was discharged from the hospital. Discharge criteria were; adequate mobilization, adequate pain management with oral analgesics, patient's willingness to be discharged, no fever, the ability to eat a soft diet, no vomiting/nausea, and no major complication. One week after discharge, all patients were invited to the outpatient clinic for early follow-up. Written clinical pathway was distributed to the surgical team members responsible for patient care, and they were educated on the items of the path.

Before the implementation of $\mathrm{CP}$, there was no specific written protocol on items such as nutritional counseling, postoperative diet instructions, catheter removal, drain removal, discharge criteria, and etc. Patients having gastrectomy were managed traditionally by the members of the surgical team. All surgical procedures during the study period were carried out by the same upper gastrointestinal surgeon. 
Table 1. Clinical pathway for gastric cancer surgery

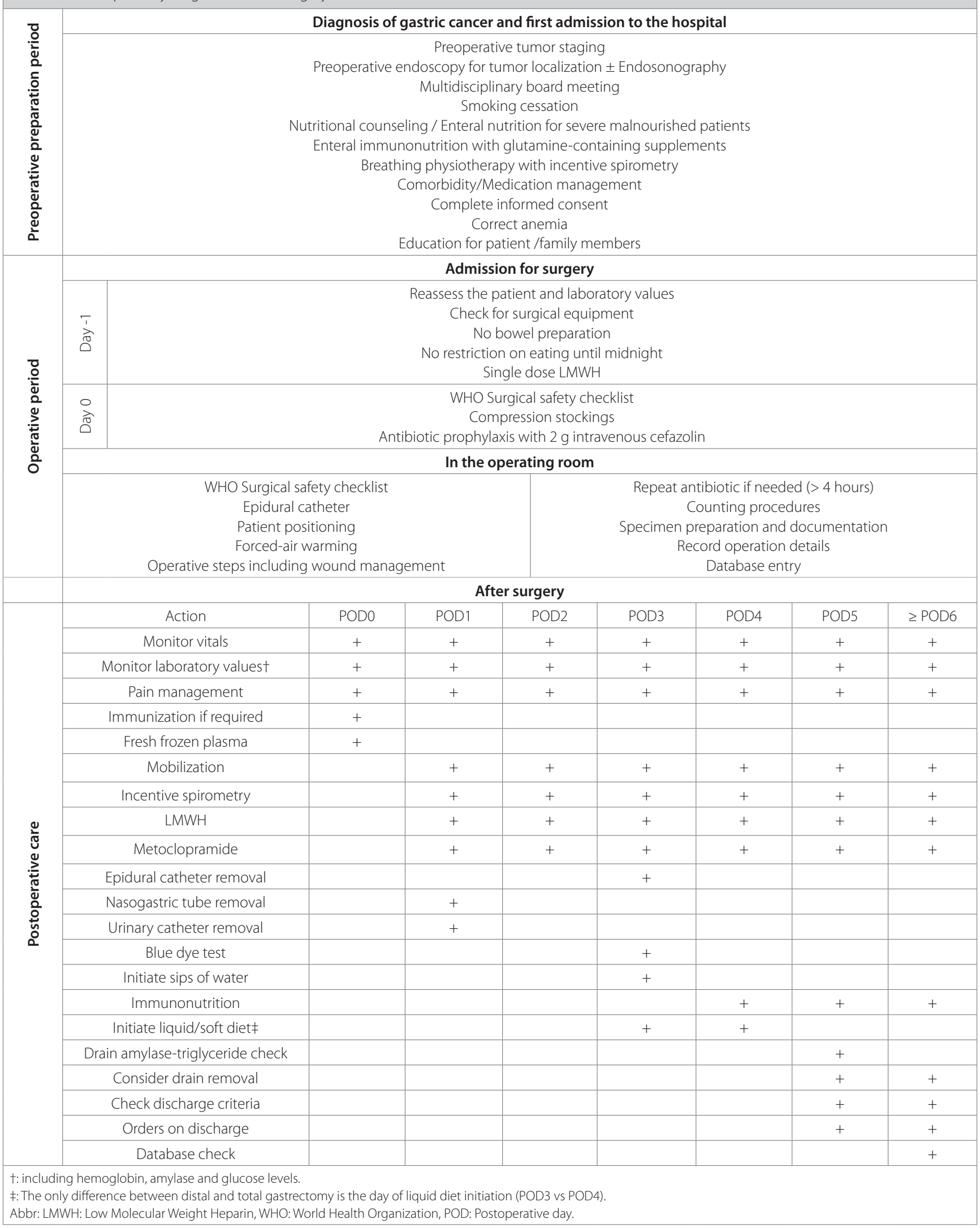




\section{Statistics Analysis}

Continuous variables were presented as mean \pm standard deviation for parametric distribution and as median ( $1^{\text {st }}-3^{\text {rd }}$ quartile) for nonparametric distribution. Chi-square test or Fisher's exact test (when $20 \%$ of expected frequencies in any cell was $\leq 5$ ), Student's t-test and Mann-Whitney test were used for comparing the groups based on the type and characteristics of the data. All p values were two-sided, and statistical significance was defined as $p<0.05$. R software (R Foundation for Statistical Computing, Vienna, Austria) with required packages was used for statistical analyses. To reduce selection bias, the "Matchlt" package with nearest-neighbor 1-1 matching was used to conduct a propensity-score matching analysis. Age, sex, albumin level, pathological stage, ASA score, and type of gastrectomy were used as covariates.

\section{RESULTS}

A total of 147 patients underwent surgery due to gastric cancer during the study period. After the application of exclusion criteria, 101 patients were included into the analysis. Among them, thirty-five patients were managed with the traditional approach (control group), and sixty-six patients were managed with the clinical pathway approach (all-CP group). Propensity score matching generated a sample of 70 patients (35 patients in the control group and 35 patients in the matched-CP group).

\section{Comparison of Baseline Characteristics Between the Groups}

The comparison of baseline patient demographics is presented in Table 2. In the non-matched analysis, there were no statistically significant differences between the control group and the all-CP group concerning sex, BMI, ASA score, history of previous abdominal surgery, smoking status, and hemoglobin levels. However, the all-CP group tended to be older (not statistically significant) and had higher albumin levels ( $p=0.049)$. In the matched analysis, there were no statistically significant differences between the control group and the matched-CP group concerning baseline patient demographics.

The comparison of oncologic and surgical factors is presented in Table 3. In the non-matched analysis, there were no statistically significant differences between the control group and the all-CP group concerning tumor size, histological differentiation, type of gastrectomy, source of tumor, neoadjuvant chemotherapy, pathological stage, and the total number of removed lymph nodes. There was a statistically significant difference in the type of lymphadenectomy. More D2 lymphadenectomy was performed in the all-CP group compared to the control group $(p=0.047)$. In the matched analysis, there was no statistically significant difference between the control group and the matched-CP group concerning the type of lymphadenectomy as well as other factors.

Table 2. Comparison of baseline patient demographics

\begin{tabular}{|c|c|c|c|c|c|}
\hline \multirow[b]{3}{*}{ Variables } & \multirow{3}{*}{$\begin{array}{l}\text { Control group } \\
\qquad \begin{array}{l}n=35\end{array}\end{array}$} & \multicolumn{4}{|c|}{ Clinical pathway group } \\
\hline & & \multicolumn{2}{|c|}{ All-CP group } & \multicolumn{2}{|c|}{ Matched-CP group } \\
\hline & & $n=66$ & $p^{\dagger}$ & $\mathrm{n}=35$ & $p^{\ddagger}$ \\
\hline Age (years) & $59.57 \pm 11.61$ & $63.92 \pm 12.04$ & 0.083 & $60.71 \pm 13.04$ & 0.700 \\
\hline \multicolumn{6}{|l|}{ Sex } \\
\hline Female & $14(40 \%)$ & $18(27.3 \%)$ & 0.190 & $11(31.4 \%)$ & 0.454 \\
\hline Male & $21(60 \%)$ & $48(72.7 \%)$ & & $24(68.6 \%)$ & \\
\hline Body mass index $\left(\mathrm{kg} / \mathrm{m}^{2}\right)$ & $23.44(21.45-27.62)$ & $24.70(22.51-29.31)$ & 0.188 & $24.70(22.58-29.53)$ & 0.213 \\
\hline \multicolumn{6}{|l|}{ ASA score } \\
\hline ASA I & $7(20.0 \%)$ & $6(9.1 \%)$ & 0.328 & $5(14.3 \%)$ & 0.946 \\
\hline ASA II & $18(51.4 \%)$ & $43(65.2 \%)$ & & $19(54.2 \%)$ & \\
\hline ASA III & $9(25.7 \%)$ & $16(24.2 \%)$ & & $10(28.6 \%)$ & \\
\hline ASA IV & $1(2.9 \%)$ & $1(1.5 \%)$ & & $1(2.9 \%)$ & \\
\hline Previous abdominal surgery & $7(20 \%)$ & $16(24.2 \%)$ & 0.628 & $9(25.7 \%)$ & 0.569 \\
\hline \multicolumn{6}{|l|}{ Smoking } \\
\hline Current & $7(20.0 \%)$ & $11(16.7 \%)$ & 0.769 & $4(11.4 \%)$ & 0.630 \\
\hline Ex-smoker (< 6 weeks) & $1(2.9 \%)$ & $5(7.6 \%)$ & & $3(8.6 \%)$ & \\
\hline Ex-smoker (> 6 weeks) & $8(22.8 \%)$ & $18(27.2 \%)$ & & $9(25.7 \%)$ & \\
\hline Never smoked & $19(54.3 \%)$ & $32(48.4 \%)$ & & $19(54.3 \%)$ & \\
\hline Hemoglobin (g/dL) & $11.65 \pm 1.89$ & $11.90 \pm 2.03$ & 0.543 & $11.85 \pm 2.10$ & 0.667 \\
\hline Albumin (g/dL) & $3.60(3.10-3.90)$ & $3.80(3.40-4.20)$ & 0.049 & $3.60(3.10-4.10)$ & 0.552 \\
\hline
\end{tabular}


Table 3. Comparison of oncologic and surgical factors

\begin{tabular}{|c|c|c|c|c|c|}
\hline \multirow[b]{3}{*}{ Variables } & \multirow{3}{*}{$\begin{array}{l}\text { Control group } \\
\qquad \begin{array}{l}n=35\end{array}\end{array}$} & \multicolumn{4}{|c|}{ Clinical pathway group } \\
\hline & & \multicolumn{2}{|c|}{ All-CP group } & \multicolumn{2}{|c|}{ Matched-CP group } \\
\hline & & $n=66$ & $\mathrm{p}^{\dagger}$ & $n=35$ & $\mathrm{p}^{\ddagger}$ \\
\hline Tumor size $(\mathrm{cm})$ & $6.00(2.75-8.00)$ & $5.00(3.50-7.00)$ & 0.892 & $5.20(4.25-9.25)$ & 0.406 \\
\hline $\begin{array}{l}\text { Histology } \\
\text { Differentiated } \\
\text { Undifferentiated }\end{array}$ & $\begin{array}{l}16(45.7 \%) \\
19(54.3 \%)\end{array}$ & $\begin{array}{l}35(53.0 \%) \\
31(47.0 \%)\end{array}$ & 0.484 & $\begin{array}{l}14(40 \%) \\
21(60 \%)\end{array}$ & 0.629 \\
\hline $\begin{array}{l}\text { Type of gastrectomy } \\
\text { Extended TG } \\
\text { TG } \\
\text { DG }\end{array}$ & $\begin{array}{l}4(11.4 \%) \\
10(28.6 \%) \\
21(60.0 \%)\end{array}$ & $\begin{array}{l}9(13.6 \%) \\
11(16.7 \%) \\
46(69.7 \%)\end{array}$ & 0.373 & $\begin{array}{l}5(14.3 \%) \\
9(25.7 \%) \\
21(60.0 \%)\end{array}$ & 0.921 \\
\hline $\begin{array}{l}\text { Type of lymphadenectomy } \\
\text { D1/D1+ } \\
\text { D2 }\end{array}$ & $\begin{array}{c}9(25.7 \%) \\
26(74.3 \%)\end{array}$ & $\begin{array}{c}7(10.6 \%) \\
59(89.4 \%)\end{array}$ & 0.047 & $\begin{array}{c}6(17.1 \%) \\
29(82.9 \%)\end{array}$ & 0.382 \\
\hline $\begin{array}{l}\text { Source } \\
\text { EGJ } \\
\text { Stomach }\end{array}$ & $\begin{array}{c}3(8.6 \%) \\
32(91.4 \%)\end{array}$ & $\begin{array}{c}8(12.1 \%) \\
58(87.9 \%)\end{array}$ & 0.743 & $\begin{array}{c}4(11.4 \%) \\
31(88.6 \%)\end{array}$ & 1 \\
\hline Neoadjuvant CT & $3(8.6 \%)$ & $8(12.1 \%)$ & 0.743 & $4(11.4 \%)$ & 1 \\
\hline $\begin{array}{l}\text { Pathologic stage } \\
\text { Stage I } \\
\text { Stage II } \\
\text { Stage III }\end{array}$ & $\begin{array}{l}8(22.8 \%) \\
5(14.3 \%) \\
22(62.9 \%)\end{array}$ & $\begin{array}{l}14(21.2 \%) \\
21(31.8 \%) \\
31(47.0 \%)\end{array}$ & 0.145 & $\begin{array}{l}7(20 \%) \\
7(20 \%) \\
21(60 \%)\end{array}$ & 0.809 \\
\hline Removed lymph nodes (n) & $35.00(28.50-42.00)$ & $36.00(28.25-46.75)$ & 0.612 & $36.00(26.50-45.00)$ & 0.801 \\
\hline
\end{tabular}

Baseline demographics, oncological factors, and surgical factors were well balanced between the control group and the matched-CP group.

\section{Comparison of Postoperative Outcomes Between the Control Group and the Matched-CP Group}

Postoperative clinical outcomes are presented in Table 4. Significantly shorter hospital stay (median 11 days vs. 9 days, $p<$ 0.001), earlier nasogastric tube removal (median 4 days vs. 2 days, $p<0.001$ ), shorter time from surgery to first SOW (median 4 days vs. 4 days, $p<0.001$ ) and soft diet (median 5 days vs. 5 days, $p=0.013$ ) were observed in the matched-CP group compared to the control group. There was no statistically significant difference between the control group and the matched-CP group concerning time to drain removal (median 6 days vs. 6 days, $\mathrm{p}=0.851$ ).

The overall complication rate was lower in the matched-CP group, while there was no statistically significant difference in major complication rates. Sixty percent of the patients in the control group and $31.4 \%$ of the patients in the matched-CP group experienced complications $(p=0.016)$. Only one pa- tient (2.9\%) in the control group and two patients (5.7\%) in the matched-CP group experienced major complications. Besides, although there was no difference in terms of the distribution of complication grades, 20 patients (57.1\%) in the control group and nine patients $(25.7 \%)$ in the matched-CP group experienced grade-I or grade-II complications ( $p=0.007)$.

Neither anastomotic leakage nor bleeding was observed in the study population. Major complications were as follows: A patient from the control group experienced right pleural effusion following extended total gastrectomy, and tube thoracostomy was required. A patient from the matched-CP group was readmitted to the hospital after discharge (on postoperative $21^{\text {st }}$ day) with the complaint of acute mechanical small bowel obstruction. Adhesive band was found during surgery; the problem was solved with adhesiolysis, and the patient was discharged three days after reoperation. One other patient from the matched-CP group (with no surgery-related complication) experienced operative mortality on the $4^{\text {th }}$ postoperative day due to cardiac arrest. No statistically significant difference was observed between the groups in terms of reoperation and operative mortality. 


\begin{tabular}{|c|c|c|c|}
\hline Variables & $\begin{array}{l}\text { Control group } \\
\quad(n=35)\end{array}$ & $\begin{array}{l}\text { CP group } \\
(n=35)\end{array}$ & p \\
\hline Hospital stay (days) & $11.00(9.00-12.50)$ & $9.00(7.00-10.00)$ & $<0.001$ \\
\hline Nasogastric tube removal (days) & $4.00(3.00-4.50)$ & $2.00(2.00-2.00)$ & $<0.001$ \\
\hline Sips of water (days) & $4.00(4.00-5.00)$ & $4.00(3.00-4.00)$ & $<0.001$ \\
\hline Soft diet (days) & $5.00(5.00-6.00)$ & $5.00(5.00-5.50)$ & 0.013 \\
\hline Drain removal (days) & $6.00(6.00-7.00)$ & $6.00(6.00-7.00)$ & 0.851 \\
\hline All complications & $21(60 \%)$ & $11(31.4 \%)$ & 0.016 \\
\hline Major complications & $1(2.9 \%)$ & $2(5.7 \%)$ & 1 \\
\hline Grade I-II complication & $20(57.1 \%)$ & $9(25.7 \%)$ & 0.007 \\
\hline Reoperation & 0 & $1(2.9 \%)$ & 1 \\
\hline Operative mortality & 0 & $1(2.9 \%)$ & 1 \\
\hline \multicolumn{4}{|l|}{ Complication grade } \\
\hline Grade I & $8(38.1 \%)$ & $3(27.3 \%)$ & 0.558 \\
\hline Grade II & $12(57.1 \%)$ & $6(54.5 \%)$ & \\
\hline Grade III & $1(4.8 \%)$ & $1(9.1 \%)$ & \\
\hline Grade IV & 0 & 0 & \\
\hline Grade V & 0 & $1(9.1 \%)$ & \\
\hline
\end{tabular}

\section{DISCUSSION}

The presented study investigated the influence of implementing a clinical pathway for patients undergoing elective gastric cancer surgery. Although both groups were comparable in terms of clinically relevant baseline characteristics, propensity score matching was used to decrease potential selection bias. Patients in the clinical pathway group demonstrated shorter hospital stay, earlier removal of the nasogastric tube, shorter time to diet while there was no difference in drain removal time. Using a clinical pathway also demonstrated less overall complication rate without increasing major complications.

Although the concept of peri-operative interventions is defined by different names such as ERAS, fast-track, critical pathway, and clinical pathway, the primary purpose is to optimize the patient in the preoperative period, to reduce the metabolic stress resulting from surgical trauma during the operation and to return to normal life as soon as possible $(27,28)$. Early studies for enhanced recovery protocols on gastrectomy for gastric cancer has started in Far Eastern countries where early-stage cancers constituted the majority of patients $(16,29)$. In subsequent studies, the implementation of various protocols by each institute has made the standardization of enhanced recovery problematic. In 2014, the first comprehensive and evidence-based framework recommendations were published (20). A total of 25 items, 8 of which were procedure-specific, included different recommendation grades with different evidence levels. While deciding on the clinical pathway in our practice, we used institutional factors and personal experiences in addition to the available evidence and recommendations. Most of the general items (not-procedure specific) were included in our clinical pathway except for the items related to anesthesia. Among procedure-specific items, preoperative nutrition (strong recommendation), preoperative oral immunonutrition (weak recommendation), and systematic audit (strong recommendation) were included in our clinical pathway. However, we showed a selective approach in the use of some crucial elements of ERAS such as the use of laparoscopic surgery (strong recommendation for early gastric cancer requiring distal gastrectomy, weak recommendation for advanced gastric cancer and total gastrectomy), selective use of nasogastric decompression (strong recommendation), avoiding the use of abdominal drain (strong recommendation) and very early initiation of diet (weak recommendation). Surgical dogmas, as well as personal experiences, are likely to have affected this selective approach, even for highly experienced gastric cancer surgeons (30). However, the implementation of a novel approach has always been slow due to surgical dogmas but has finally been. It is to our belief that all essential items may be included in clinical pathway with increasing evidence and experience.

One of the most important goals of the clinical pathway concept is shortening hospital stay, and shorter hospital stay was demonstrated in the presented study (median 11 days vs. 9 
days, $p<0.001)$. Many factors, such as the defined discharge criteria in the clinical pathway group, earlier removal of the nasogastric tube, earlier initiation of oral food intake, and fewer complications may affect this shortening. Shortened hospital stay has been demonstrated in randomized studies evaluating the feasibility of enhanced recovery programs in gastric cancer patients. In the first randomized controlled trial, median hospital stay was six days in the fast-track protocol group, while the conventional group had 8-days length of hospital stay ( $p<$ 0.001) (29). In a subsequent randomized trial, shorter hospital stay has also been demonstrated in an enhanced recovery group (median 10 days vs. 9 days, $p=0.037$ ) (31). Besides, in a recent study from the United States, the ERAS group has demonstrated shorter hospital stay with a mean difference of 2.3 days (mean $7.8 \pm 3.6$ days vs. $5.5 \pm 2.0$ days, $p=0.010$ ) (18). The only study that showed that the ERAS program did not affect the length of hospital stay was the study published in Japan in 2012 (32). However, as the authors indicated, this result was probably due to the item "normal laboratory data on POD 7" which was included in the discharge criteria. Although the median 9-day hospital-stay in the presented study, which included mostly stage-III patients, is comparable to previous reports, we believe that this period may be shortened more by modifying the criteria together with the increasing experience.

The biggest drawback of surgeons in the implementation of an enhanced recovery program is the possibility of increased complication rates. However, until now, there has been no increase in complication rates in both ERAS studies and studies that are specific to ERAS items. On the contrary, fewer complications have been obtained in the enhanced recovery group compared to the conventional group (31). In the presented study, Clavien-Dindo classification system was used to define the severity of the complications, and a decrease in the overall complication rate was demonstrated ( $60 \%$ vs. $31.4 \%, p=0.016)$. While there was no significant difference between the two groups in major complications, particularly the difference in grade I/II complication rates $(57.1 \%$ vs. $25.7 \%, p=0.007)$ likely caused this improvement. The patients were more optimized for surgery with the help of the preoperative items such as nutritional support, breathing physiotherapy, and patient education on the process. In addition to optimal patient, postoperative care items such as early mobilization may explain the decrease in non-major complications.

When creating the presented clinical pathway protocol, not only the enhanced recovery items but also surgical safety issues as part of surgical quality improvement were considered. In the "Optimal Resources for Surgical Quality and Safety" manual published by the American College of Surgeons in 2017, physician-led, team-based care was emphasized, and surgical care divided into five phases (33). Four of these phases were present in the presented clinical pathway; only the items for the post-discharge period were not included. In the future, the creation of systems using various tools, not only enhanced recovery items but also items from all phases of peri-operative care, will help us develop an ideal patient care program. Implementing a peri-operative patient care program is more feasible in developed countries such as the United States and Japan, in developing countries like Turkey, there is still a way to go. However, the presented study showed that better outcomes could be achieved by integrating evidence-based models into practice.

The presented clinical pathway protocol has some points that need to be improved. Most importantly, we used a surgeon-led structure with the support of the members of the surgical team, ward nurses, and surgical residents to develop the protocol. However, ideal clinical pathway should be designed by a multidisciplinary team consisting of anesthesiologists, dieticians, and physiotherapists. Anesthesia-related items, which are the significant shortfall in the presented pathway, can only be resolved with a multidisciplinary approach. Another point that needs to be improved is the more use of the laparoscopic approach. The evidence on the feasibility and oncological safety of laparoscopic surgery in advanced gastric cancer is still being waited and possibly will be integrated into the algorithm in the near future $(34,35)$.

The presented study has an unavoidable selection bias, which is one of the main limitations of retrospective studies. Although patient characteristics such as age, sex, stage, type of gastrectomy were comparable in both groups, lymphadenectomy and albumin levels were different. Therefore, propensity-score matching was used to reduce selection bias, and ultimately, appropriately comparable groups were obtained. Another possible limitation in comparison with the historical cohort is the experience bias, although a single surgeon performed all surgeries. Early-period records were excluded to decrease this bias, and the study was limited to a narrow period. Despite these limitations, the presented study supports the contribution of clinical pathway to enhanced recovery in patients undergoing gastric cancer surgery in a developing country. Multidisciplinary, multicenter studies in which outcome measures such as cost analysis, compliance rates, patient experiences, and quality of life are included have more potential to demonstrate the effectiveness of enhanced recovery programs.

\section{CONCLUSION}

Clinical pathway can safely be implemented for patients undergoing elective gastric cancer surgery. Using clinical pathway may shorten the postoperative length of hospital stay and reduce the rate of complications without increasing major morbidity. 
Ethics Committee Approval: Ethics permission for the study was obtained from the ethics committee (2019/177).

Informed Consent: Written consent of all the patients was received.

Peer-review: Externally peer-reviewed.

Author Contributions: Concept - A.G.; Design - A.G.; Supervision - A.G.; Resource - A.G.; Data Collection and/or Processing - A.G.; Analysis and/or Interpretation - A.G.; Writing Manuscript - A.G.; Critical Reviews - A.G.

Conflict of Interest: There is no conflict of interest in this study.

Financial Disclosure: This study has no financial support.

\section{REFERENCES}

1. Grumbach K, Lucey CR, Johnston SC. Transforming from centers of learning to learning health systems: the challenge for academic health centers. JAMA 2014 19;311(11):1109-10. [CrossRef]

2. Chakravarty A, Parmar NK, Ranyal RK. Total quality management the new paradigm in health care management. Med J Armed Forces India 2001;57(3):226-9. [CrossRef]

3. Lynn PA. Relationship between total quality management, critical paths, and outcomes management. Semin Nurse Manag 1996;4(3):163-7. [CrossRef]

4. Carman JM, Shortell SM, Foster RW, Hughes EF, Boerstler H, JL OB, et al. Keys for successful implementation of total quality management in hospitals. Health Care Manage Rev 2010;35(4):283-93. [CrossRef]

5. Sihoe $A D$. Clinical pathway for video-assisted thoracic surgery: the Hong Kong story. J Thorac Dis 2016;8(Supp/ 1):S12-22. [CrossRef]

6. Tastan S, Hatipoglu S, Iyigun E, Kilic S. Implementation of a clinical pathway in breast cancer patients undergoing breast surgery. Eur J Oncol Nurs 2012;16(4):368-74. [CrossRef]

7. Campillo-Soto A, Martin-Lorenzo JG, Liron-Ruiz R, Torralba-Martinez $J A$, Bento-Gerard M, Flores-Pastor B, et al. Evaluation of the clinical pathway for laparoscopic bariatric surgery. Obes Surg 2008;18(4):395400. [CrossRef]

8. Ovaere S, Boscart I, Parmentier I, Steelant PJ, Gabriel T, Allewaert J, et al. The effectiveness of a clinical pathway in liver surgery: a case-control study. J Gastrointest Surg 2018;22(4):684-94. [CrossRef]

9. Refai M, Salati M, Tiberi M, Sabbatini A, Gentili P. Clinical pathway for thoracic surgery in an Italian centre. J Thorac Dis 2016;8(Supp/ 1):S238. [CrossRef]

10. van der Kolk M, van den Boogaard M, Ter Brugge-Speelman C, Hol J, Noyez L, van Laarhoven $K$, et al. Development and implementation of a clinical pathway for cardiac surgery in the intensive care unit: effects on protocol adherence. J Eval Clin Pract 2017;23(6):1289-98. [CrossRef]

11. Uslu A, Zengel B, Ilhan E, Aykas A, Simsek C, Ureyen O, et al. Survival outcomes after D1 and D2 lymphadenectomy with $R 0$ resection in stage II-III gastric cancer: longitudinal follow-up in a single center. Turk J Surg 2018;34(2):125-30. [CrossRef]

12. Ozmen MM, Ozmen F, Zulfikaroglu B. Lymph nodes in gastric cancer. J Surg Oncol 2008;98(6):476-81. [CrossRef]

13. Bartlett EK, Roses RE, Kelz RR, Drebin JA, Fraker DL, Karakousis GC. Morbidity and mortality after total gastrectomy for gastric malignancy using the American College of Surgeons National Surgical Quality Improvement Program database. Surgery 2014;156(2):298-304. [CrossRef]
14. Cetin DA, Gundes E, Ciyiltepe H, Aday U, Uzun O, Deger KC, et al. Risk factors and laboratory markers used to predict leakage in esophagojejunal anastomotic leakage after total gastrectomy. Turk J Surg 2018 20:1-6. [CrossRef]

15. Sugisawa N, Tokunaga M, Makuuchi R, Miki Y, Tanizawa Y, Bando E, et al. A phase II study of an enhanced recovery after surgery protocol in gastric cancer surgery. Gastric Cancer 2016;19(3):961-7. [CrossRef]

16. Kim JW, Kim WS, Cheong JH, Hyung WJ, Choi SH, Noh SH. Safety and efficacy of fast-track surgery in laparoscopic distal gastrectomy for gastric cancer: a randomized clinical trial. World J Surg 2012 Dec;36(12):2879-87. [CrossRef]

17. Gatenby PA, Shaw C, Hine C, Scholtes S, Koutra M, Andrew H, et al. Retrospective cohort study of an enhanced recovery programme in oesophageal and gastric cancer surgery. Ann R Coll Surg Engl 2015;97(7):502-7. [CrossRef]

18. Desiderio J, Stewart CL, Sun V, Melstrom L, Warner S, Lee B, et al. Enhanced Recovery after Surgery for Gastric Cancer Patients Improves Clinical Outcomes at a US Cancer Center. J Gastric Cancer 2018;18(3):230-41. [CrossRef]

19. Ding J, Sun B, Song P, LiU S, Chen H, Feng M, et al. The application of enhanced recovery after surgery (ERAS)/fast-track surgery in gastrectomy for gastric cancer: a systematic review and meta-analysis. Oncotarget 2017;26;8(43):75699-711. [CrossRef]

20. Mortensen K, Nilsson M, Slim K, Schafer M, Mariette C, Braga M, et al. Consensus guidelines for enhanced recovery after gastrectomy: Enhanced Recovery After Surgery (ERAS ${ }^{\circledR}$ ) Society recommendations. Br J Surg 2014;101(10):1209-29. [CrossRef]

21. Guideline Committee of the Korean Gastric Cancer Association DWG, Review P. Korean Practice Guideline for Gastric Cancer 2018: an Evidence-based, Multi-disciplinary Approach. J Gastric Cancer 2019;19(1):1-48. [CrossRef]

22. Japanese Gastric Cancer A. Japanese gastric cancer treatment guidelines 2014 (ver. 4). Gastric Cancer. 2017;20(1):1-19. [CrossRef]

23. Guner A. Recent trends of gastric cancer treatment in Turkey. Transl Gastroenterol Hepatol 2017;2:31. [CrossRef]

24. Amin MB, Greene FL, Edge SB, Compton CC, Gershenwald JE, Brookland RK, et al. The Eighth Edition AJCC Cancer Staging Manual: Continuing to build a bridge from a population-based to a more "personalized" approach to cancer staging. CA Cancer J Clin 2017;67(2):93-9. [CrossRef]

25. Guner A, Son T, Cho I, Kwon IG, An JY, Kim HI, et al. Liver-directed treatments for liver metastasis from gastric adenocarcinoma: comparison between liver resection and radiofrequency ablation. Gastric Cancer 2016;19(3):951-60. [CrossRef]

26. Dindo D, Demartines N, Clavien PA. Classification of surgical complications: a new proposal with evaluation in a cohort of 6336 patients and results of a survey. Ann Surg 2004;240(2):205-13. [CrossRef]

27. Gundogdu H, Ersoy E, Recep A, Hakan K, Mehmet O, Vedat O, et al. Evaluation of nutritional risk on admission to the general surgery department. Bratis/ Lek Listy 2008;109(2):57-60. [CrossRef]

28. Ersoy E, Gundogdu H. Enhanced recovery after surgery. Turk J Surg 2007;23(1):35-40. [CrossRef]

29. Wang D, Kong Y, Zhong B, Zhou X, Zhou Y. Fast-track surgery improves postoperative recovery in patients with gastric cancer: a randomized comparison with conventional postoperative care. J Gastrointest Surg 2010;14(4):620-7. [CrossRef] 
30. Jeong O, Kim HG. Implementation of Enhanced Recovery after Surgery (ERAS) Program in Perioperative Management of Gastric Cancer Surgery: a Nationwide Survey in Korea. J Gastric Cancer 2019;19(1):7282. [CrossRef]

31. Tanaka R, Lee SW, Kawai M, Tashiro K, Kawashima S, Kagota S, et al. Protocol for enhanced recovery after surgery improves short-term outcomes for patients with gastric cancer: a randomized clinical trial. Gastric Cancer 2017:20(5):861-71. [CrossRef]

32. Yamada T, Hayashi T, Cho H, Yoshikawa T, Taniguchi H, Fukushima R, et al. Usefulness of enhanced recovery after surgery protocol as compared with conventional perioperative care in gastric surgery. Gastric Cancer 2012;15(1):34-41. [CrossRef]
33. American College of Surgeons. Optimal Resources for Surgical Quality and Safety. In: Hoyt DB, Ko CY, Jones RS, Cherry R, Schneidman D, Khalid M (eds). $1^{\text {st }}$ ed. Chicago, IL: American College of Surgeons, 2017. [CrossRef]

34. Zulfikaroglu B, Koc M, Ozmen MM, Kucuk NO, Ozalp N, Aras G. Intraoperative lymphatic mapping and sentinel lymph node biopsy using radioactive tracer in gastric cancer. Surgery 2005;138(5):899-904. [CrossRef]

35. Guner A, Hyung WJ. Minimally invasive surgery for gastric cancer. Ulus Cerrahi Derg 2014;30(1):1-9. [CrossRef]

\title{
ORIJINAL ÇALIȘMA-ÖZET
}

\author{
Turk J Surg 2020; 36 (1): 39-47
}

\section{Mide kanseri cerrahisinde klinik yolak kullanımının etkinliği}

\author{
Ali Güner ${ }^{1,2}$ \\ ${ }^{1}$ Karadeniz Teknik Üniversitesi Tıp Fakültesi, Genel Cerrahi Anabilim Dalı, Trabzon, Türkiye \\ ${ }^{2}$ Karadeniz Teknik Üniversitesi Tıp Bilimleri Enstitüsü, Biyoistatistik ve Tıp Bilişimi Anabilim Dalı, Trabzon, Türkiye
}

\section{ÖZET}

Giriş ve Amaç: Klinik yolaklar cerrahi kalitenin iyileştirilmesinde kullanılan yararlı araçlardır ve majör cerrahi geçiren hastalarda ameliyat sonrası daha iyi klinik sonuç elde edilmesinde yardımcı olur. Bu çalışmada, mide kanseri hastalarında klinik yolak kullanımının erken postoperatif sonuçlar üzerine olan etkisinin değerlendirilmesi amaçlanmıştır.

Gereç ve Yöntem: Bu çalışma retrospektif bir kohort çalışma olarak dizayn edildi. Prospektif olarak kayıt yapılan veritabanından, mide kanseri nedeniyle ameliyat edilen hastaların verileri elde edildi. Hastalar klinik yolağın kullanıma girdiği tarihe göre iki gruba ayrıldı: kontrol grup (Mayıs 2015-Mayıs 2016) ve klinik yolak grubu (Haziran 2016-Aralık 2017). Eşleştirilmiş gruplarda hastaların hastanede kalış süresi, oral gıda başlama zamanı ve 30 gün komplikasyon oranları gibi erken dönem klinik sonuçları karşılaştırıldı.

Bulgular: Toplam 101 hasta analiz edilmiştir ve eşleştirme sonrası 70 hastanın (her grupta 35 hasta) verileri karşılaştııılmıştır. Klinik yolak grubundaki hastaların daha kısa süre hastanede kaldığı, nazogastrik tüpün daha erken çıkarıldığı ve sıvı/yumuşak gıdaya daha erken dönemde başlandığı tespit edilmiştir. Tüm komplikasyon oranı klinik yolak grubunda daha düşük iken, majör komplikasyon açısından gruplar arasında istatistiksel açıdan fark görülmemiştir. Reoperasyon ve mortalite açısından da istatistiksel olarak anlamlı bir fark saptanmamıştır.

Sonuç: Klinik yolak kullanımı mide kanseri nedeniyle elektif ameliyat edilen hastalarda hastanede kalış süresini kısaltabilir ve majör komplikasyonu artırmadan tüm komplikasyon oranlarını azaltabilir.

Anahtar Kelimeler: Gastrektomi, mide kanseri, klinik yolak, perioperatif bakım, fonksiyonların düzelmesi, kalitenin geliştirilmesi

Doi: $10.5578 /$ turkjsurg.4547 